\title{
Glimpses of Our Merdeka
}

Iqbal $U^{*}$ and Mohd Salleh MN

Faculty of Social Sciences and Humanities, National University of Malaysia, Malaysia

*Corresponding author: Iqbal U, Faculty of Social Sciences and Humanities, National University of Malaysia, 43650 UKM, Bangi Selangor, Malaysia, Tel: 60389215555; E-mail: uqbah@siswa.ukm.edu.my

Received date: October 27, 2015, Accepted date: October 30, 2015, Published date: November 5, 2015

Copyright: () 2015 lqbal U et al. This is an open-access article distributed under the terms of the Creative Commons Attribution License, which permits unrestricted use, distribution, and reproduction in any medium, provided the original author and source are credited.

\section{Introduction}

This paper contains a collection of Radio Television Malaysia (RTM) interviews with members of MHS to commemorate the 43rd anniversary of independence. The theme 'The Meaning of Independence' (Erti Kemerdekaan) will always be discussed when we celebrate our independence but there are times we feel its significance tend to lose its gloss and patriotic fervor especially among the younger generation. Malaysian Historical Society feels the old interviews are still relevant as they serve as supplementary record to the historic and arduous journey to independence achieved 54 years ago. The paper is called 'Glimpses of Our Merdeka' as Malaysian Historical Society humbly realizes that the book contain limitations, namely the articles are short and have no academic pretensions. But they are readable, interesting and personal and should be able to provide rich source and insights into our 'Merdeka' that could well evoke pride and inspirations.

\section{History of Books or Journals}

Malaysian Historical Society is conscious of the limitations and constraints of our modern reader who have no time and opportunity to glean on heavy or academic writings in history books or journals. 'Glimpses of Our Merdeka' would be the answer as the articles are brief without losing the essence of the subject matter. Malaysian Historical Society hopes their readers would be stimulated to seek advanced reading on this momentous period which only occurs once in the history of a nation. "Glimpses of Our Merdeka" contains fourteen articles or essays, nine of which were originally the substance of a series of interviews conducted by Radio Television Malaysia (RTM) in August, 2000 at the Head Office of the Malaysian Historical Society/MHS or Persatuan Sejarah Malaysia/PSM at JKR No. 958, Jalan Hose, Kuala Lumpur.

The interviews were part of a RTM programmed called 'The Meaning of Independence' on the occasion of the celebration of Malaysia's Independence on 31st August 2000. The interviews were aired over RTM Radio 4 during the month of August 2000. The series of interviews were with two members of the Council of the MHS and seven members of the Executive Committee of the MHS, each with a specific topic having a bearing on Malaysia's Indepence. Dato Haji Omar Mohd Hashim, Chairman of Executive Comittee MHS discuss topic on 'Merdeka: Its Meaning and the Long Arduous Struggle to Achieve It', Dato' Haji Dol Ramli, Deputy Chairman of Executive Committee MSH discuss topic on 'The Japanese Conquest of Malaya and Singapore and Its Aftermath', Dato' Haji Jumaat Dato' Haji Mohd Noor, Honorary Treasurer and Member of Executive Committee MHS discuss topic on 'The Emergency: Some Recollections of Events in A District', Haji Abdul Rahman Mohd Ali, Assistant Honorary Treasurer and Member of Executive Committee MHS discuss topic on 'A Brief Account of Events Leading to Independence (1957), Dato' Prof.
Emeritus Dr. Mohd Taib Osman, Member of the Council MHS discuss topic on 'The Part Played by the Resurgence of Malay Literary Interests in Achieving Independence, Dato' Asiah Abu Samah, Member of the Council MHS discuss topic on 'The Concept and Meaning of Independence and the Role of Women in Attaining Independence, Dato' Nik Mohamed Nik Mohd Salleh, Member of Executive Committee MHS discuss topic on 'The Malayan Union', Dato' Kum Boo, Member of Executive Committee MHS discuss topic on 'The Malayan Emergency, 1948-1960 and Independence; Home Guards, the Unsung Heroes' and Encik DJ Muzaffar Tate, Member of Executive Committee MHS discuss topic on 'European Penetration and Colonialism in Malaysia'.

Five other articles are 'The Malayan Administrative and Diplomatic Service (formerly The Malayan Civil Service) in Service of the Nation' by Dato' Seri Mohamed Khalil Haji Hussein, Vice President of Pegawai Tadbir dan Diplomatik Alumni (Alumni PTD), 'Promise of the Chinese Community Still Undelivered', an interview of the late Prof. Dr. Nik Anuar Nik Mahmud by Harakah and published in the Harakah issue of 1-15 August 2007, 'Article 153 intended for Long Term' by Tan Sri Abdul Aziz Abdul Rahman, published in The New Straits Times on 6 July 2008, 'Malaysia: Federal-States Relations' (Original title: Remembering Malaysia Day by Dr. Shad Saleem Faruqi, published in the Star on 17 September 2008), 'Seven Wills of the Malay Rulers', the text of the address by Yang Teramat Mulia Raja Muda Perak Darul Ridzuan Raja Dr. Nazrin Shah Ibni Sultan Azlan Muhibbuddin Shah, the Crown Prince of Perak, published by Utusan Malaysia on 7 August 2009. The original Malay version was translated into English by Encik Mohd Arof Ishak, a member of the Executive Committee MHS. The Seven Wills were delivered by the Malay Rulers at the time when they were attesting their signature to the Agreement to the Constitution of the Federation of Malaya on 5 August 1957.

This book is very important because a publication relating to the country's independence is a valuable one. It is important not only in adding to the collection of thoughts on an event of such great importance to the country, but also in terms of contributing towards developing sense of patriotism and awareness of the labour of the people in creating a unified, independent, and sovereign nation. It is also a show of appreciation for the all-important efforts to provide content to the fact of independence, which would guarantee the preservation of that independence. Those who never had the experience of living during colonial times might think that independence is just a mundane matter. In a way, such thinking may cause us to be neglected on the subject of the importance of defending our independence, more so in the exhilaration over globalisation, and the various subtle pressures, if we are not vigilant enough, will cause a threat to the preservation of our independence, in its truest sense.

Malaysian Historical Society hopes their effort will encourage others to produce better books on Merdeka to meet the needs of our rakyat 
Citation: Iqbal U, Mohd Salleh MN (2015) Glimpses of Our Merdeka. Arts Social Sci J 6: e102. doi:10.4172/2151-6200.1000e102

Page 2 of 2

especially the younger citizens of today. In the foreword, the Prime Minister of Malaysia and President of Malaysian Historical Society, Dato' Sri Najib Tun Abdul Razak also hope more individuals and organisations will produce writings on the subject of our country's independence in the future. This is because the country's history belongs to us all. It lives forever, hence any interested persons may write on their own experiences, readings, and no less important perceptions, interpretations, and thinking. That is what makes history so interesting - a reflection of our lives. 